Markos Valéria

Debreceni Egyetem Humán Tudományok Doktori Iskola

\title{
A fogadószervezetek koordinátorainak tapasztalatai az iskolai közösségi szolgálatról
}

\section{Bevezetés}

M agyarországon a rendszerváltást követő gazdasági, társadalmi és politikai átalakulás utat nyitott a civil szervezetek létrejöttének. Az állami és piaci szektor különválásával egyre inkább megnőtt az igény egy harmadik szektor kialakítására, amely olyan társadalmi szükségleteket kíván kielégíteni, melyre sem az állami, sem a piaci szektor nem alkalmas. A civil szervezetekben való önkéntes részvétel - azon túl, hogy számos pozitív hozadékkal jár mind az egyén, mind a társadalom számára egy újfajta szocializációs csatornaként jelenik meg a fiatalok életében. A különböző civil szervezeteknél elsajátított viselkedésmód elösegítheti a fiatalokat aktívabb társadalmi részvételét a szükebb és tágabb környezetükben.

Az OECD (Eurobarometer 75.2, 2011) és a Központi Statisztikai Hivatal adatai (Az önkéntes munka jellemzői, 2016) adatai mind azt bizonyítják, hogy hazánkban a nyugati országokhoz képest jóval alacsonyabb az önkéntes tevékenységet végzők aránya. Szükségszerüvé vált egy olyan központi, állami intézkedés, mely elősegíti az önkéntes szerepvállalás tudatosítását az állampolgárok körében a lehető legfiatalabb korban. Így 2012-ben bevezetésre került az iskolai közösségi szolgálat, melynek céljai között szerepel az állampolgári aktivitás és az önkéntes szerepvállalás elősegítése. Ahhoz, hogy az iskolai közösségi szolgálat elérje említett céljait, a civil szféra részéről egy olyan befogadó és együttmüködő közegre van szükség, mely segíti azt, hogy a fiatalok középiskolás éveik alatt olyan pozitív állampolgári mintát és attitüdöket sajátítsanak el, mely a jövőben képes lesz társadalmi szinten is kimutatható pozitív hozadékot teremteni.

Tanulmányom célja megvizsgálni a civil társadalomban való részvétel egyéni és társadalmi hatásait, empirikus úton feltárni a fogadószervezetek attitüdjeit és tapasztalatait a közösségi szolgálattal kapcsolatban. Kutatási kérdéseim elsősorban arra irányulnak, hogy milyen előnyökkel és hasznosulással jár a fogadószerveztek számára a közösségi szolgálatos diákok fogadása, és a koordinátorok meglátása szerint milyen társadalmi hasznot nyújt a program bevezetése. A közösségi szolgálat kiforratlanságából adódóan számos megoldásra váró problémával néznek szembe a diákok (Markos, 2015), valószínüsíthetően a fogadószervezetek koordinátorai is, melyet jelen tanulmányban részletesebben is kifejtek.

\section{A civil aktivitás mikro- és makroszintü jellemzői}

Az 1960-as és 1970-es években felbukkanó társadalmi mozgalmak, melyek politikai célokkal rendelkeznek, de nem törekszenek a politikai hatalom megszerzésére, társadalmi problémákra próbálnak szervezett válaszokat adni. Aktívabb állampolgári részvételre buzdítanak, az erőszakmentesség elvét szem elött tartva, és ehhez az aktivitáshoz igyekszenek megteremteni a színtereket. A civil társadalom az állam, a társadalom és a gazdaság viszonyrendszerében egy új pozíciót foglal el, de ezen újdonság ellenére maga a fogalom nem új, esetleg csak annak használata. A civil társadalom fogalmának történeti áttekintése során három elkülönült értelmezési időszakot különíthetünk el. Már 
az ókori gondolkodóknál megjelent a fogalom első, tradicionális értelmezése, mely az állam és a társadalom között még nem tesz különbséget. A modern értelmezés elkülöníti és szembe is állítja egymással az államot és a társadalmat. A közelmúlt értelmezései pedig az állam mellett már a gazdaságot is leválasztják a fogalomról, így kirajzolódnak a civil társadalom ma leginkább használt jellemzői, határai (Cohen és Arató, 1992a):

- kormányzati szervektöl független,

- nem profitorientált,

- önkéntes módon szerveződő,

- különböző társadalmi szervezetek, egyesületek.

A civil szervezetekben való tagságnak vagy önkéntes munkavégzésnek pozitív hatása és hozadéka van mind a társadalom, mind az egyén számára. A civil szervezetek fontos szocializációs csatornák fiatal és felnőttkorban egyaránt, hiszen a szervezetekben való tevékenység során olyan viselkedésmódot sajátíthat el és gyakorolhat az egyén, mely szükséges az aktív részvételen alapuló demokrácia megvalósításához és müködéséhez (Kuti, 1996; Vajda, 1997; Glózer, 2000).

A különböző ifjúsági szervezetekhez, vagy a tanintézményekben müködö diákönkormányzatokhoz való csatlakozás által a fiatalok olyan élmények és információk birtokába juthatnak, és olyan képességekkel gazdagodhatnak, melyek szocializációjuk tekintetében meghatározóak. Segít kialakítani bennük a civil tudatosságot, a másokon való segítésre való hajlandóságot, a társadalmi cselekvésekbe kapcsolódáshoz szükséges viszony kialakulását és az önkéntességre való hajlandóságot (Nárai, 2004).

A nemzetközi szakirodalom szerint, ha valaki korai életszakaszában (középiskola, felsőoktatási évek) önkéntes munkát végez, vagy részt vesz valamilyen egyesületben, az növeli a felnőttkori állampolgári aktivitást, és később is nagyobb hajlandóságot mutat majd az az effajta viselkedésre, azaz növeli a jövőbeni önkéntesség kialakulását (Brow, 1999b; Smith, 1999; Wilson és Musick, 1999).

Brown (1999b) szerint az önkéntességgel kapcsolatos fiatalkori élmények és tapasztalatok hozzájárulnak a felnőttkori önkéntes részvétel ösztönzéséhez. A fiatalok információt kaphatnak az aktív társadalmi részvétel lehetőségeiről és fontosságáról, megtapasztalhatják az önkifejezés ezen módját, és nem utolsó sorban megtapasztalhatják azt a pszichikai állapotot, mely mások megsegítéséből ered.

Putnam $(1995,2000)$ szerint minél többen kapcsolódnak be civil szervezetek, klubok, egyesületek munkájába, annál erősebb az egyének közötti érzelmi és információs háló, annál nagyobb bizalom és együttmüködési készség alakul ki a társadalomban. Putnam a bizalom kapcsán kiemeli, hogy a szervezetben való tevékenység során az egyéneknek meg kell bízniuk egymásban, azaz, akik együtt dolgoznak, nem fognak a közös céllal ellentétesen cselekedni. Az együttmüködés alapja tehát a bizalom, mely az individuumok kölcsönhatásán keresztül jön létre. Putnam egy jól működő társadalomban a személyes kapcsolatok fontosságát hangsúlyozza, hisz a civil szervezetekben való részvétel, a tagság fontossága abból adódik, hogy a szerveződések elsősorban a tartós közösségi kapcsolatok révén képesek a társadalmi töke létrehozására és közvetítésére, így a társadalmi struktúra erősítésére. Putnam a bizalom, a hálózatok (kapcsolatok) és az állampolgári felelősségtudat együttesében találta meg a demokrácia müködésének kulcsát (Wollebaak és Selle, 2002).

A civil szervezetek hálózati kiterjedtségének hiányában a társadalom atomizálódik, melynek következménye, hogy hiányoznak azok az erők, melyek az egyéni érdekek 
diverzitását kollektív érdekké tudnák egységesíteni. Így tehát a civil szféra kiterjedtsége a társadalom jó müködésének egyik fontos mutatója (Kuti, 1998).

\section{A civil szervezeti tagság jellemzői Magyarországon}

Magyarországon a 80-as évek végéig nem igazán volt jelen a köztudatban a civil aktivitás és önkéntes munkavégzés jelensége. Ugyan korábban is működtek önkéntes és civil szervezetek (pl. KISZ, Nőszövetség, Hazafias Népfront), de ezek elsődleges célja a párt és annak politikájának a támogatása volt. Ugyanakkor a Központi Statisztikai Hivatal (KSH) jelentései alátámasztják az civil szervezetek meglétét, habár rendszertelenül és szervezetlenül müködtek, hisz a szervezetek nagy része nem tudatosan foglalkoztatott önkénteseket (F. Tóth és Nagy, 2009).

A rendszerváltás idején a törvényi változásokkal párhuzamosan jelentős mértékben kezdett növekedni a föképpen önkéntes munkán alapuló egyesületek és egyletek száma; többségük bekapcsolódott a szociális feladatok ellátásába is. Fő céljuk az volt, hogy megpróbáljanak megoldási javaslatokat kialakítani a fennálló társadalmi problémákra. A harmadik szektor fellendülése több lépésben ment végbe. Bizonyos civil tevékenységek kibontakozása - például a kultúra vagy a természetvédelem területén - már a nyolcvanas években kezdetét vette. Igazán lényeges változást az 1987-es Polgári Törvénykönyv módosítása hozott, hisz ekkor megnyílt a lehetőség az alapítványok létrehozására, majd ezt követően 1988-ban megalakult egy adórendszer is, ami lehetővé tette a civil szektor támogatását. 1989-ben jelent meg az a rendelet, amely visszaállította az egyesülés teljes szabadságát (Szigeti, 2003).

A KSH az úgynevezett társas nonprofit szervezetek - mely magában foglalja többek között az egyesületeket, klubokat, köröket - gyarapodásával méri az önkéntesség és civil aktivitás növekedését. Ezek a szervezetek többségében kis létszámmal, fizetett alkalmazott nélkül vagy kis létszámú fizetett alkalmazott foglalkoztatásával müködnek. Elsősorban baráti, érdeklődési, szomszédsági, területi vagy szakmai csoportok, ahol a feladatokat maguk a szervezet tagjai látják el, bármiféle fizetség ellenében. Természetesen az alapítványok is alkalmazhattak önkénteseket, de a klasszikus önkénteseket foglalkoztató szervezeteknek a társas nonprofit szervezetek tekinthetők. A nonprofit szervezetek számának növekedése a csúcsot 2009-ben érte el, amikor is 66145 ilyen szervezet müködött. 2009 óta nem sikerült elérni ezt a magas arányt, azóta fokozatos csökkenés érzékelhető (1. ábra, Czike és Kuti, 2006). 


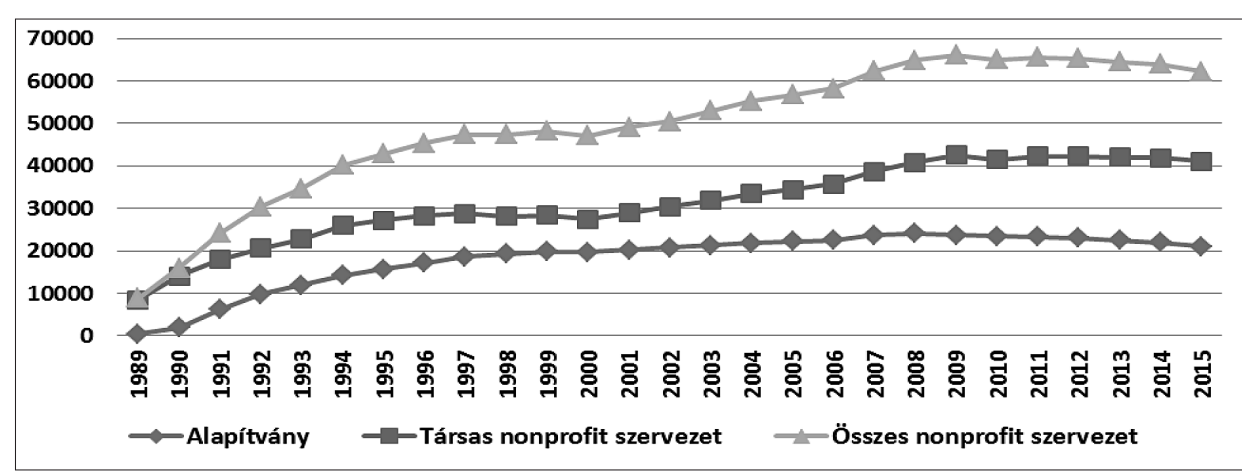

1. ábra A társas nonprofit szervezetek alakulása Magyarországon 1989-2015 (ezer fö) (Forrás: KSH, 2016; Nemzeti Önkéntes Stratégia, 2012-2020)

A civil társadalom alapját képző önkéntes szektor feltételeinek javítása egyfajta figyelemfelhívást is jelent az önkéntesség szükségszerüségére, jelentőségére és népszerüsítésére. Hazánkban a szociális ellátás területén elsősorban a civil szervezetek által felkínált önkéntes tevékenységek a jellemzőek. Az egyéni felajánlások - egyéni segítők - megjelenése még igen ritka és föként a területi ellátásban jelenik meg (például a házi gondozásban). Az önkéntes segítő munka presztízsének növeléséhez és az önkéntes segítők számának emeléséhez nagymértékben hozzájárultak azok a főiskolai/egyetemi képzések (például a szociális munkás), tanfolyami képzések (szociális gondozó), amelyek az elmúlt néhány évben kínálják szolgáltatásaikat (Zentai, 2006).

Magyarország az OECD-adatok alapján a közepes önkéntes aktivitású országok közé tartozik. ${ }^{1}$ Annak okát, hogy Magyarországon az ezredfordulót követően az önkéntesek száma még mindig jóval elmarad a nyugati országokéhoz képes a következőkkel magyarázzák (Bocsi, Fényes és Markos, 2017; Szigeti, 2003):

- a pozitív szülöi és/vagy társadalmi minta hiánya,

- a hagyományos közösségek felbomlása (például urbanizációs okok),

- a civilek szervezési készségeinek hiányossága,

- emberi erőforrások hiánya (mivel kevés a fizetett alkalmazott a szervezeteknél, azok hiányában nem képes a szervezet megfelelően bánni az újonnan érkezö önkéntesekkel),

- az emberek pénzkeresésért vívott küzdelme (a nyugati országokéhoz képest kevesebb idő jut szabadidős programokra),

- a megfelelő törvényi háttér hiánya,

- hiányzik az önkéntesség megfelelő társadalmi súlya.

Ha kifejezetten az ifjúsági civil szervezeteket vizsgáljuk, megállapítható, hogy jelenleg a magyar társadalom nincs felkészülve arra, hogy a fiatalok a szocializációjuk során elsajátítsák a társadalmi részvétel és felelősségvállalás formáit. Jancsák (2007) szerint nincs kellően biztosítva az a keretrendszer, ahol mintát kaphatnak a fiatalok arról, hogy hogyan sajátítsák el a demokrácia eszközeit, valamint az állampolgári tudatosság és a civil magatartás jellemzőit.

Ha az elmúlt évek Magyar Ifjúság $(2012,2016)$ kutatásait vizsgáljuk, látható, hogy a fiatalok szervezetekhez való csatlakozásának aránya hasonló mintázatot mutat. Míg 2012-ben a megkérdezettek 23\%-a, 2016-ban 25\%-a vallotta azt, hogy tagja valamilyen

${ }^{1}$ Eurobarométer 75.2. (2011) adatai alapján. Az önkéntesek számát jelentősen meghatározza az önkéntesség definíciója, mely a vizsgálatok során gyakran eltérő lehet. 
szervezetnek. A fiatalok elsősorban sportkluboknak és sportegyesületeknek tagjai, melyet a diák- és hallgatói valamint szabadidős szervezetek követnek. A lista negyedik helyét a környezetvédelmi és természetvédelmi, állatvédelmi szervezetek követik. Az adatok azt mutatják, hogy a fiataloknak csak egy igen szűk rétege tagja politikai szervezetnek. Ha a társadalmi háttértényezőket is figyelembe vesszük, megállapítható, hogy a magasabb arányú szervezeti kötődés a jó státuszú szülők magasan iskolázott gyerekeinél kimutatható, azaz a diplomával rendelkezők vagy jelenleg felsőoktatásban tanulókra jellemző inkább (Székely, 2012; Bauer és mtsai, 2016).

Látható tehát, hogy szükségszerü olyan intézkedéseket szorgalmazni, melyek orvosolják ezeket a problémákat. Többek között ilyen lehet az Amerikai Egyesült Államokban és Nyugat- Közép Európa több országában már jól bevált módszerként jelen lévő úgynevezett service-learning. Kelet-Európában - ahol a civil szervezetek és a civil aktivitás hasonló jellegzetességekkel bír, mint Magyarországon - eddig alig jelentek meg ilyen jellegü programok. Magyarországon az iskolai közösségi szolgálat tehát egy hatékony program lehet arra vonatkozóan, hogy a civil aktivitással és társadalmi felelősségvállalással kapcsolatos mutatók a közép- és nyugat-európai országok mintázatához közelítsenek.

\section{Az iskolai közösségi szolgálat tartalmi kritériumai és céljai}

A 2011. évi CXC. törvény 4.§ 15. pontja határozza meg az iskolai közösségi szolgálat fogalmát. A rendelet így definiálja a közösségi szolgálatot: „Szociális, környezetvédelmi, a tanuló helyi közösségének javát szolgáló, szervezett keretek között folytatott, anyagi érdektöl független, egyéni vagy csoportos tevékenység és annak pedagógiai feldolgozása.” A törvény továbbá arra is kitér, hogy a 2016. január 1-jét követően az érettségi bizonyítvány kiadásának feltétele, a diákok ötven óra közösségi szolgálat teljesítésének igazolása. Az iskola szervezett keretei között kell szociális vagy karitatív tevékenységet folytatni (Nemzeti Köznevelésről szóló 2011. évi CXC. törvény, 4.§ (15.), 6§ (4.)).

A középiskolák kötelessége a közösségi szolgálat megszervezése. Ennek elérése érdekében, az iskolai igazgatója által felkért pedagógus, az úgynevezett iskolai koordinátor folyamatosan vezeti és dokumentálja a közösségi szolgálattal kapcsolatos egyéni vagy csoportos tevékenységeket, a fogadóintézményekkel és szervezettekkel való kapcsolatfelvételt és kapcsolattartást. A koordinátor az 50 óra keretén belül öt óra felkészítő és öt óra értékelő, záró foglalkozást tart a diákok számára. A 9-12. évfolyamos tanulóknak az 50 óra közösségi szolgálatot arányosan elosztva, lehetöleg három tanév során kell teljesíteniük. A tevékenység alkalmanként tanítási napokon legalább egy, de legfeljebb három óra, tanítási napokon kívül legkevesebb egy, legfeljebb öt órás időkeretben van meghatározva. (Nemzeti Köznevelésröl szóló 2011. évi CXC. törvény, 4.§ (15.), 6§ (4.)).

Bodó Márton (2014) iskolaigazgatók, pedagógusok körében végzett monitoringvizsgálatainak eredményei szerint a pedagógusok a közösségi szolgálattal kapcsolatban problémaként az információhiányt és a gyakorlati tapasztalatok hiányát említették. A válaszadók 66\%-a a 2012/2013-as tanév végén csak hallomásból ismerte, míg 80\%-a még nem vett részt közösségi szolgálat szervezésében. Annak ellenére, hogy a 2012-es tanévben a közösségi szolgálat bevezetésre került, a vizsgálati eredmények szerint a tanév második felében az iskolák jelentős része még nem volt tisztában azzal, hogy mi is valójában a közösségi szolgálat.

Bodó Márton 2015-ben online kérdöíves adatfelvételt végzett szintén pedagógusok, koordinátorok és intézményvezetők körében. A kérdőív nagy hangsúlyt fektetett arra, hogy vizsgálja a pedagógusok, elsősorban a koordinátori szerepet betöltők munkamotivációit. Az eredmények azt mutatták, hogy a koordinátorok mindössze 13,4\%-ának van személyes indíttatása, mely komoly veszélyt jelenthet a közösségi szolgálat sikeres- 
ségére. Lényeges hangsúlyozni, hogy a koordinátorok motivációja jelentős mértékben befolyásolja a diákok motivációját, ezért fontos, hogy a legmegmotiváltabb és legelkötelezettebb személy töltse be ezt a pozíciót. A kutatási eredmények szerint azonban a döntést az iskolavezető a személyes motiváció feltérképezésén túl az alapján hozza meg, hogy kiknek van megfelelő tapasztalata, felkészültsége, kapcsolatrendszere és kapacitása a szervezéshez. A személyes indíttatás aránya tehát csekély. További problémaként jelenik meg, hogy a pedagógusok a 22-26 órás munkaidejükön túl, a szabadidejük terhére szervezik a közösségi szolgálatot. A koordinátor a 26 óra megtartásán túl nem képes az adminisztráción felül bármilyen más tevékenységet végezni (mely nem is várható el), így a szervezési feladatokat átterheli a diákokra és a szülőkre. Ebből következik, hogy a felkészítő, illetve levezető órák sem történnek meg. Fontos lenne tehát a koordinátorok anyagi vagy természetbeni jutalmazása ahhoz, hogy a közösségi szolgálat minél sikeresebb legyen (Bodó, 2016).

A szolgálat teljesítésére iskolán belül és kívül is van lehetőség. Iskolán kívül civil vagy nonprofit szervezeteknél, állami, önkormányzati, egyházi intézményeknél, szervezeteknél, de magánszemélynél is teljesíthető a szolgálat. Ez utóbbi esetben az iskola, egy ernyőszervezet vagy egyéb koordináló szervezet lehet a fogadóintézmény. Szakszervezetnél, politikai szervezetnél, pártoknál nem teljesíthető az iskolai közösségi szolgálat.

A közösségi szolgálat során a diák köteles az iskola által készített közösségi szolgálati naplót vezetni, mellyel igazolja az 50 óra elvégzését. A napló tartalmazza, hogy a diák mikor, hol, milyen időkeretben és milyen tevékenységeket folytatott. A diákok kizárólag olyan segítő tevékenységet végezhetnek, melyek szakképzettséget nem igényelnek, és az nem az intézmény munkatársainak munkaköri feladata. A feladat teljesítését a fogadóintézmény koordinátora aláírásával igazolja. A szolgálat többféle területre kiterjedhet, úgymint:

- egészségügyi,

- szociális és jótékonysági,

- oktatási,

- kulturális és közösségi,

- környezet- és természetvédelmi,

- katasztrófavédelmi,

- óvodáskorúakkal, sajátos nevelési igényü gyermekekkel, tanulókkal, idős emberekkel közös sport- és szabadidő (Nemzeti Köznevelésről szóló 2011. évi CXC. törvény, 133.§ (2.)).

A közösségi szolgálat egyik fö célja, hogy lehetőséget biztosítson az alulról jövő kezdeményezéseknek, hogy a diák információkkal gazdagodjon a civilségröl, önszerveződésről és önkéntességröl, és hogy erösítse a fiatalok számára a későbbi önkéntes elköteleződést. A program egyfajta érzékenyítési folyamat a közjó és segítségnyújtás felé. Lényeges eleme, hogy a diák szembekerül a valósággal, munkája során hasznosnak és értékesnek érezheti magát a társadalom számára, növeli önbizalmát, önismeretét, fejleszti állampolgári elköteleződését. A közösségi szolgálat során elért teljesítmény nem függ össze a tanuló tanulmányi eredményével, így a tanulási nehézségekkel küzdő diákok is sikereket érhetnek el a programban (Bodó és Schnellbach, 2014). 
A közösségi szolgálat során az általános célok keverednek a pedagógiai célokkal. A szolgálat lehetővé teszi a diákoknak, hogy fejlesszék személyes és szociális kompetenciáikat, közvetlen tapasztalati tanulás által. A közösségi szolgálatnak kihívásnak, élvezetesnek kell lennie, egyfajta személyes utazásnak önmagunk felfedezéséhez. A tanulók nem ugyanazon szintről indulnak, így eltérőek a célkitüzéseik és szükségleteik is. Az iskolai közösségi szolgálat akkor lesz sikeres, ha a diák számára fel van kínálva a lehetőség, hogy több tevékenységből választhasson, és a végzett tevékenység igazodik a tanuló személyiségéhez. Fontos, hogy az érintett szereplők, azaz a diákok, a fogadószervezetek és a pedagógusok tájékozottak legyenek, és rendelkezzenek a megfelelő információval. Továbbá, hogy a közösségi szolgálatot felkészítő óra előzze meg, és levezető óra zárja, mely során megtörténik a reflexió és az élmények megosztása (Galambos és Matolcsi, 2012; Matolcsi, 2013; Rozgonyi, 2014).

2015-ben fókuszcsoportos interjúk segítségével vizsgáltuk a 10-11. évfolyamos középiskolás diákok iskolai közösségi szolgálattal kapcsolatos tapasztalatait. Különbségek mutatkoztak a gimnáziumba járó és a szakközépiskolába járó diákok közösségi szolgálat iránti attitűdjeikben is. Bár mindkét csoport elsősorban kényszerként, kötelezettségként fogta fel a közösségi szolgálatot, a gimnazisták érzékelték annak hosszú távú céljait, és azt, hogy milyen pluszelőnyökkel járhat későbbi életük során. A szakközépiskolába járó diákok elmondásuk alapján nem törekszenek arra, hogy a tanult szakmájukhoz hasonló területen végezzék a szolgálatot. Még ha lenne rá lehetőségük, akkor sem. Egyes esetekben - ha mégis kapcsolódott a terület a tanulmányokhoz - a szolgálat során olyan kisegítő feladatokat végezhettek a diákok, ami nem segítette szakmai tapasztalatszerzésüket. A két oktatási intézménytípus közötti különbség adódhat abból, hogy a gimnáziumokban esetleg magasabb szintű a közösségi szolgálatra való felkészítés minősége, vagy több információval látják el a diákokat, de adódhat akár a gimnazisták érdeklődőbb hozzáállásából vagy jobb társadalmi hátteréből is (Markos, 2015; Markos, 2016a).

2016-os kvantitatív kutatásunkban tovább vizsgáltuk a tapasztalatok és az iskolatípus közötti összefüggéseket. Az eredmények szerint az iskola típusa és a szak jelentős mértékben befolyásolja a fiatalok iskolai közösségi szolgálattal kapcsolatos tapasztalatait, mind a területválasztást, mind a területválasztás motivációját és azt, hogy hol teljesítik a közösségi szolgálatot. A felkészítő és a feldolgozó órák meglétében és hiányában is kimutatható volt a szignifikáns összefüggés iskolatípusonként. A kutatás továbbá rávilágít arra is, hogy a diákok elsősorban az óvodáskorú, sajátos nevelési igényü gyermekekkel, tanulókkal, idős emberekkel közös sport- és szabadidős területen folytatható tevékenységet választják. Magas arányban választották még a diákok a szociális és jótékonysági, a környezetvédelmi, valamint kulturális és közösségi területet is. A diákok által legkevésbé választott terület a katasztrófavédelmi és az egészségügyi terület volt (Markos, 2016a).

\section{A kutatás részletei}

Kutatásom legfőbb kérdése a civil szervezetek oldaláról, hogy vajon milyen előnyökkel és nehézségekkel jár a fogadószervezetek számára a közösségi szolgálatos diákok fogadása, valamint, hogy a diákok mennyire képesek a szervezet számára valóban hasznos tevékenységet végezni. A koordinátorok oldaláról, hogy mennyire motiváltak a diákok a közösségi szolgálat elvégzése után további önkéntes munkavégzésre, valamint, melyek azok a problémák a közösségi szolgálattal kapcsolatban, melyek megoldásra várnak.

Kutatási kérdéseimre kvalitatív módszerrel kerestem választ. Korábban a diákok iskolai közösségi szolgálattal kapcsolatos attitüdjeit vizsgáltam (Markos, 2015; 2016a; 
2016b), mely során nyilvánvaló lett, hogy a diákok többsége milyen területen működő fogadószervezetnél végzi a közösségi szolgálatot. Jelen kvalitatív kutatásomban a résztvevőket ez alapján választottam ki, azaz olyan területeket vontam be, ahol jellemzően nagyobb arányban töltik a diákok a közösségi szolgálatot. Ez segítséget nyújt ahhoz, hogy még mélyebben megismerhessük a diákok attitüdjeit, és segítséget kaphassunk a korábbi eredmények értelmezéséhez. Interjúvázlatom a következő témaköröket tartalmazta: a közösségi szolgálat definíciója, céljai, a diákok és a koordinátorok motivációi, tapasztalatai és jövőképük. Terjedelmi korlátok miatt jelen tanulmányomban csak a dimenziók egy részét dolgozom fel.

Kutatásomban kilenc személlyel készítettem félig strukturált interjút. A fogadószervezetek anonimitása érdekében a tevékenységi területek alapján különböztettem meg a fogadószervezetek koordinátorait. A különböző területeken végzett tevékenységeket az 1. táblázat foglalja össze. A tevékenységi területek a következők voltak:

- Szociális és jótékonysági terület: hátrányos helyzetủ családok segítésével, munkaerő-piaci integrációjával foglalkozó civil szervezet; vakokat és gyengén látókat támogató egyesület.

- Kulturális és közösségi terület: ifjúsági iroda, közösségi tér; önkéntes központ; bábszínház; könyvtár.

- Környezet- és természetvédelmi terület: Állatvédő alapítvány, állatmenhely.

- Katasztrófavédelmi terület: Katasztrófavédelmi igazgatóság.

- Sport és szabadidő: Játszóház.

1. táblázat: A különbözö tevékenységi területeken végezhető tevékenységek

\begin{tabular}{|c|c|c|c|c|}
\hline $\begin{array}{c}\text { Szociális } \\
\text { és jótékonysági } \\
\text { terület ( } 2 \text { db) }\end{array}$ & $\begin{array}{c}\text { Kulturális } \\
\text { és közösségi terület } \\
\text { (4 db) }\end{array}$ & $\begin{array}{l}\text { Környezet- és } \\
\text { természet-védelmi } \\
\text { terület }(1 \mathrm{db})\end{array}$ & $\begin{array}{c}\text { Katasztrófa- } \\
\text { védelmi terület } \\
(1 \mathrm{db})\end{array}$ & $\begin{array}{c}\text { Sport } \\
\text { és szabadidős } \\
\text { terület }(1 \mathrm{db})\end{array}$ \\
\hline $\begin{array}{c}\text { - Kreatív } \\
\text { foglalkozás } \\
\text { gyerekek számára, } \\
\text { - Nyári táboroztatás } \\
\text { - Dekoráció } \\
\text { készítése } \\
\text { - Vakok számára } \\
\text { érettségi tételek } \\
\text { felolvasása, } \\
\text { hanganyag készítése } \\
\text { - Irodai feladatok: } \\
\text { borítékolás, postára } \\
\text { küldés } \\
\text { - Vakok személyes } \\
\text { segítése }\end{array}$ & $\begin{array}{l}\text {-Terem-berendezés } \\
\text { - Logisztika } \\
\text { - Díszletkészítés, } \\
\text { varrás, barkácsolás }\end{array}$ & $\begin{array}{l}\text { - Kutyasétáltatás, } \\
\text { fürdetés, } \\
\text { kennel-takarítás } \\
\text { - Kertgondozás }\end{array}$ & $\begin{array}{c}\text {-Tüzoltó } \\
\text { alaptanfolyamon } \\
\text { való részvétel } \\
\text { - Előadásokon való } \\
\text { részvétel } \\
\text { - Megismerkedés } \\
\text { a tűzoltósági eszkö- } \\
\text { zökkel }\end{array}$ & $\begin{array}{l}\text { - Gyerek- } \\
\text { felügyelet } \\
\text { - Gyerek- } \\
\text { foglalkozáso- } \\
\text { kon való } \\
\text { részvétel } \\
\text { - Gyerekek } \\
\text { étkeztetésének } \\
\text { segítése }\end{array}$ \\
\hline
\end{tabular}

A táblázat alapján megállapítható, hogy a diákok által végzett tevékenységek nem minden esetben kapcsolódnak közvetlenül a választott intézmény tevékenységi és müködési köréhez. Például a szociális és jótékonysági terület kapcsán látható, hogy nem 
minden esetben végeznek a fiatalok szociális tevékenységet, gyakran irodai feladatokat, vagy dekorációs tevékenységet folytatnak, mely során nem biztos, hogy közvetlenül kapcsolatba kerülnek a választott célcsoporttal.

Az irányított beszélgetés során igyekeztem a résztvevők véleményét, gondolatait és tapasztalatait a lehető legmélyebb módon feltárni. Az interjúk alatt többségében sikerült egy informális légkör megteremtése. Tanulmányom során a megfigyeléseimet és következtetéseimet interjúrészletekkel támasztom alá.

\section{Önkéntes vagy „50 órás” diák?}

A civil szervezetek munkatársai az iskolai közösségi szolgálat fogalmát gyakran helyettesítik az önkéntesség fogalmával. Ez a fogalmi zavar a korábbi kvalitatív kutatásunk során is megjelent a diákok körében (Markos, 2015). A beszélgetésünk elején tehát fontosnak tartottam tisztázni néhány alapvető fogalmat, amelyek szükségszerüen felmerülnek az interjú során. Elsőként arról kérdeztem a koordinátorokat, hogy szerintük mit jelent az iskolai közösségi szolgálat, és miben különbözik az önkéntesség fogalmától.

„Az önkéntességet, azt úgy definiáljuk, hogy szabadidömben, önként akaratomból, teljesen ingyen és bérmentve teszek a jóért és a közért. Míg a közösségi szolgálatban pedig egy kötelezöen elöirt 50 óra van, ami szükséges feltétele az érettségi szolgálatnak, vagyis az érettséginek. Úgyhogy ezt kötelezöen meg kell csinálniuk." (Kulturális és közösségi terület)

„Az önkéntesség, mint a nevében is benne van, az illetö önszántából végzi, tehát saját elhatározásából elmegy egy intézménybe vagy egy szervezethez vagy egy alapitványhoz, és felajánlja magától a segitségét. Az iskolai közösségi szolgálat pedig olyan szempontból nem hasonlit az önkéntességhez, hogy ez kötelezö. Tehát ezt teljesiteni kell a diáknak, amiben viszont hasonlit az önkéntességhez, hogy fizetést, azt természetesen nem kapnak érte a diákok." (Szociális és jótékonysági terület)

Látható, hogyha külön a közösségi szolgálat és külön az önkéntesség definíciójára kérdezünk rá, a koordinátorok érzékelik a fö különbséget a kettő között; azonban a fogalomtisztázást követően a beszélgetés során továbbra is többször a közösségi szolgálat szinonimájaként használták az önkéntes, egyes esetekben a közmunka kifejezést. Az egyik koordinátor nem csak a fogalomhasználatban, de a diák hozzáállásában is érzékeltette a különbséget az önkéntesek és a közösségi szolgálatot teljesítő diákok között.

„Hát én, ahogy látom - ezt inkább tapasztalatból mondom -, hogy ugye közösségi szolgálatnál azt látom, hogy ez egy kötelezö dolog a diákoknak, és ez sokszor érezhetö is, hogy nem biztos, hogy olyan szivesen vannak itt. Hogyha valamire megkérjük öket, lehet, picit húzogatják a szájukat, hogy nem tetszik az nekik, viszont aki önkéntesen jön, ö tényleg bármit. Nem is kell neki mondani, észreveszi azt, hogy meg kell csinálni, tudja, hogy mi a dolga. Szívesen van itt, egész idö alatt mosolyog, hogy ez a lelkesedés, ami úgy nagyon látszik." (Sport és szabadidős terület)

Az, hogy a diákok mennyire szívesen végzik a közösségi szolgálati tevékenységet a koordinátorok szerint elsősorban a motivációjukra vezethető vissza. Jelentős különbség mutatkozik az önkéntes és közösségi szolgálatos diák munkamotivációja között, ez 
utóbbi valószínűleg köszönhető a szolgálat kötelező jellegének. Gyakori azonban, hogy nem csak a diákok, de a koordinátorok hozzáállása is más az önkéntes és közösségi szolgálatot teljesítő diákokhoz, mely a tevékenységek kiosztásában is megmutatkozik. Jellemző, hogy míg a közösségi szolgálatot végző diákok számára inkább a fizikai munka jut, addig az önkéntesek a kevésbé megterhelö, inkább kikapcsolódást és szórakoztatást elősegítő tevékenységeket végzik.

„,Kutyaséta, tehát általában kutyaséta, és ha van néhány ilyen munkálat, például, hogy szél volt, nagyon összefújta a falevéllel, vagy itt a betonon vagy fünyírás van, tehát olyankor szoktuk adni ezt, hogy akkor egy kicsit segitsenek be ebbe. Általában kutyasétáltatás, nyáron szokott olyan előfordulni, hogy kutyát fürdettek, vagy, hogy ök locsoltak a kennelekben, ugye ebben a nagy höségben, hogy ne föjenek meg szegénykék. Néha, amikor látjuk, hogy tényleg ilyen szorgalmas az önkéntes, és tényleg szivesen megcsinál bármit, akkor volt olyan, hogy mosogatott edényeket. De ez ritka, ezt tényleg csak olyan, aki tényleg nagyon kis szorgalmas és lelkiismeretes. Tehát a legtöbbször kutyát sétáltatnak.

$K$ : Az önkéntesek is és a közösségi szolgálatos diákok is ugyanazt a tevékenységet végzik?

V: Tehát az 50 órások szokták ezeket a tevékenységeket csinálni, amiket most elmondtam. Tehát, aki csak úgy jön, ök sétáltatnak. Tehát, aki bejön az utcáról, hogy ö sétáltatni szeretne, de hát általában ezért jönnek." (Környezet- és természetvédelmi terület)

Előfordul tehát, hogy a szolgálatot teljesítő diákok más bánásmódban részesülnek, mint önkéntes társaik. Ez azonban olyan további következményeket vonhat maga után, ami a közösségi szolgálattal kapcsolatos negatív attitüdök kialakulásának kedvez. Az eltérö bánásmód a korábbi kvalitatív kutatásunk során is megjelent, ott a diákok arról számoltak be, hogy a fiú és lány tanulók között tesznek különbségek a koordinátorok. A fiúkra gyakrabban bíztak fizikai munkákat, ami elkedvtelenítette öket (Markos, 2015).

A rosszul megválasztott tevékenységek, így az ezzel járó negatív tapasztalatok meggátolhatják azt, hogy a diák akár később önkéntesként visszatérjen a szervezethez; vagy épp az adott szervezethez, célcsoporthoz való jövőbeni hozzáállását negatív irányban befolyásolhatja. Fontosnak tünik tehát, hogy a fogadószervezetek olyan tevékenységeket kínáljanak a diákok számára, melyeket nem csak az önkéntesek, de a szolgálatot teljesítő fiatalok is szívesen végeznek és örömet találnak benne.

\section{Fogadóintézmények tapasztalatai a közösségi szolgálatról}

A következőkben a koordinátorok attitüdjeit vizsgáljuk a közösségi szolgálattal kapcsolatban. A koordinátorok az iskolai közösségi szolgálat legfőbb céljaként a „,munkára való nevelést”, a „pályaorientációt” hangsúlyozták, és azt, hogy ezáltal „több szakmába van lehetöségük betekinteni" a diákoknak. A közösségi szolgálat további céljai, mint az empátia, a csapatépítő készség, csak egy-egy koordinátornál jelent meg.

Az általunk megkérdezett interjúalanyok azonban mindenképpen jó dolognak tartják a szolgálatot. Úgy vélik fontos az, hogy motiválják a fiatalokat az aktívabb állampolgári létre hisz ennek nem csak társadalmi, de egyéni haszna is jelentős lehet. Hangsúlyozták, a közösségi szolgálat akkor éri el igazán a célját, ha minél több területet kipróbál a diák, és nem egy fogadóintézménynél tölti el az 50 órát.

„A kezdörugót meg kell adni nekik, és erre meg tök jó. De amúgy rengeteg tapasztalatot szerezhetnek, hogyha jól csinálják tényleg. Hogyha nem egy helyen, 
hanem, mit tudom én, 2-3 óránként változtatja a helyeket, és akkor minél szinesebb tapasztalatokat gyüjt be, annál több lesz belöle az adott fiatal." (Kulturális és közösségi terület)

Az interjúalanyok többsége - a diákokhoz hasonló módon (Markos, 2015) - a szolgálat kötelező jellegét kifogásolták. Úgy vélik, elsősorban nem a szolgálat kötelezőségére kellene felhívni a diákok figyelmét, hanem arra, hogy ez miért hasznos számukra, azaz az egyéni hasznosulását kellene hangsúlyozni.

„Nem tudom, hogy a fiatalok milyen információkat kapnak erről a közösségi szolgálatról. Tehát szerintem azt, hogy miért is van ez, hogy mi is ennek a célja, azt lehet, hogy jobban el kellene nekik mondani. (...) ezt a kötelezö dolgot nem kéne nagyon eröltetni, de tehát nem erre kellene felhívni, hogy ez kötelezö dolog, és hogy ezt meg kell csinálnotok, hogy van itt ez az 50 óra, amit az érettségi elöfeltétele, és most ezeken meg ezeken a helyeken lehet megcsinálni." (Kulturális és közösségi terület)

„Hát a kötelezö szót cserélném át valamilyen másra. Tehát átvitt értelemben lenne kötelezö, valami mást kellene kitalálni. Azt, hogy nyilván meg kell csinálni, hogy ne az a szó legyen, hogy kötelezö megcsinálni, hanem neked igen meg kell csinálni, mert hasznodra válik. De egyben legyen kötelezö, ilyen sejtelmesen legyen megfogalmazva." (Kulturális és közösségi terület)

A koordinátorok tehát a kötelezőség kommunikációs és törvényi átalakítását szorgalmazzák. Ugyanakkor többen úgy érzékelik, hogy bár 2011 óta többszöri törvénymódosításon esett át a szolgálat, máig nincs jól kidolgozva a rendszer, sem az ellenőrizhetősége, sem a törvényi szabályozása. A közösségi szolgálat köznapi kritikája, hogy nagy a visszaélés az ellenőrizhetőségével kapcsolatban, és gyakori, hogy a diákok vagy a szüleik kapcsolatrendszerének köszönhetőn közösségi tevékenységvégzés nélkül is megkaphatják az igazolást. Szinte minden interjúalanyom említette, hogy volt már olyan megkeresésre példa a diákok részéröl, hogy mindössze az órát szerette volna papíron leigazoltatni szolgálati tevékenység végzése nélkül.

„Tehát nem tudja már a fogadóintézmény dolgozója nyomon követni, hogy mi is éppen az aktuális szabály erre vonatkozóan. Illetve nem lehet utána ellenörizni, és szerintem így a csalásnak nagy az esélye." (Szociális és jótékonysági terület)

„Az, hogy talán szervezetek másként értelmezik, túlvállalják, leigazolják összevissza, nincs egy, mondjuk ellenőrzö hatósága. Most ez, hogy megnézik az érettségi elött, hogy megvan-e a pecsét vagy 50 óra, az csak egy végsö ellenörzés. Azt, hogy milyen keretek között, miért kapják, mit csinálnak, nincs egy egységes rendszer. Én úgy tudom, hogy ilyen elöírások vannak, de nincsen, hogy ezt csinálhatja, ezt nem csinálhatja. Meg van, elég szépen szabályozva, hogy öt órában, hol, hány km-re a településétöl meg az iskolától, de nem tudom." (Kulturális és közösségi terület)

Érdeklődtem arról is, hogy mennyire eredményesen tudnak részt venni az intézmények munkájában a diákok. Az interjúalanyok szerint egyértelműen a diákok hozzáállása határozza meg, hogy mennyire hasznos a munkájuk. Egyrészt beszámoltak arról, hogy gyakori jelenség, hogy a diákoknak nem sok hasznát veszik, olykor teherként tekintenek a pluszmunkaerőre, akik nem segítik, inkább korlátozzák a dolgozókat a 
saját munkavégzésükben, így pluszmunkát, időt és energiát igényel a közösségi szolgálatos diákokkal való együttmüködés.

„Volt már arra is példa, hogy hogy inkább azt éreztük, hogy teher, hogy itt van, mert többször el kellett mondani, többször kellett figyelmeztetni bizonyos dolgokra, és még akkor sem volt hajlandó úgy csinálni, vagy odafigyelni. És akkor ugye ez nekünk is plusz energia, és nem elég, hogy végzem a saját munkámat, és tényleg próbálok úgymond a kisebb gyerekekkel foglalkozni, még akkor rá is fordítsak figyelmet, idöt." (Sport és szabadidös terület)

„Úgyhogy közösségi szolgálaton belül talán az a tapasztalat, hogy öö, több olyan diák van, akivel nehezebben tudunk együttmüködni, mint olyan, akivel könnyen.' (Sport és szabadidös terület)

A másik oldalon azonban megjelenik az a vélemény is, hogy egyes fogadószervezeteknek nagy szükségünk van a plusz munkaeröre, és valóban képesek a diákok olyan tevékenységet végezni, ami az intézmény és annak célcsoportja számára is hasznos lehet.

„Hát ez nekünk is nagyon hasznos, mert van segítségünk. Tehát mi azért vagyunk itt most hatan, heten, de hogyha egy ilyen 40-50 fös rendezvényünk van, és mindenki látássérült, és nem mindenki kisérővel érkezik, nekünk az hatalmas segítség, ha tudnak segíteni, az hatalmas segitség, ha tudnak segíteni." (Szociális és jótékonysági terület)

Az elmondottak alapján látható, hogy nem rajzolódik ki egységes vélemény a koordinátorok körében a közösségi szolgálati tevékenység haszna tekintetében. Pozitív és negatív esetekről egyaránt beszámoltak az interjúalanyok. Az, hogy a diák mennyire képes eredményesen bekapcsolódni az intézményi munkába, a koordinátorok szerint a diák személyiségén, motivációján, együttmüködési készségén múlik.

\section{Állampolgári aktivitás és közösségi szolgálat}

Egyes interjúalanyok szerint a közösségi szolgálat képes növelni az egyén állampolgári aktivitását, hisz a civil szférában töltött idő gyakran ráébresztheti a fiatalokat arra, hogy van joguk és beleszólásuk a szűkebb-tágabb közösségükben folyó történésekbe. Egyfajta öntudatra ébresztheti őket, és arra, hogy a civil szervezetekkel való közös együttműködéssel megvalósíthatják elképzeléseiket.

„Mert lehet, hogy belelát egy bizonyos dologba és akkor látja, hogy ja, nekem ehhez, most ehhez is van jogom, meg ehhez is, és lehet, hogy tényleg jobban kiáll azokért a dolgokért." (Sport és szabadidös terület)

Érdeklődtem arról is, hogy a koordinátorok meglátása, tapasztalatai szerint a diákokban az iskolai közösségi szolgálat hatására nö-e a hajlandóság az önkéntesség iránt, és hajlandóbbak lennének-e a jövőben önkéntes tevékenységet vállalni, mint a közösségi szolgálat megkezdése előtt, illetve terveznek-e hasonló tevékenységet végezni, mint amit a szolgálat alatt végeztek.

„Én úgy gondolom, hogy azért hozzájárul, ha nem is minden diáknál, de, de szerintem biztos, hogy valaki ezáltal megtapasztalja, hogy jéé, de jó segíteni, 
anélkül hogy én elvárnék valamit, és a későbbiekben is valószinü, sokkal nyitottabb lesz. Már nálunk például volt erre példa." (Sport és szabadidös terület)

„Hát szerintem egy részét bátoritani fogja, és továbbra is vissza fog menni a fogadó intézményhez, vagy más helyekre, de szerintem a nagyobb részének el fogja venni a kedvét, azt gondolom." (Szociális és jótékonysági terület)

„Szerintem igen. Hogyha, hogyha, meglátja valaki a kötelezö szó mögött az önkéntes szolgálatot, és elengedi ezt a kötelezö dolgot, és ráérez az izére, akkor szerintem igen, akkor képes. Nekem is van olyan fiatalom, aki itt maradt az önkéntes szolgálat után, és szerintem nem is került volna velünk kapcsolatban soha, hogyha, hogyha, nem kötelezöen kellett volna jönnie.” (Kulturális és közösségi terület)

„De tényleg többnyire az szokott lenni, megvan az az óra, ami neki kell, és akkor soha többet nem látjuk." (Sport és szabadidős terület)

Látható, hogy a közösségi szolgálat önkéntességre gyakorolt hatásáról pozitívan és negatívan egyaránt vélekedtek az interjúalanyok. Többségüknél volt rá példa, hogy a közösségi szolgálatos diák gyarapította az önkénteseik számát, és az 50 óra elteltével tovább folytatta segítő tevékenységét. Azonban érzékelhető, hogy tömeges önkéntes társadalom megjelenéséről nem beszélhetünk, hisz intézményenként egy-egy ilyen esetről számoltak be a koordinátorok. Általánosságban nem maradnak tovább önkéntesként a diákok. Remélhető azonban, hogy a jövőben ez a szám gyarapodni fog, hisz a rendszer kiforratlanságai máig érzékelhetőek. Ezek orvoslása elősegítheti az önkéntesség gyarapodását, melyre a koordinátorok is bizakodva tekintenek.

\section{Problémák a közösségi szolgálattal kapcsolatban}

Végül arról kérdeztem az interjúalanyokat, hogy a gyakorlatban hogy látják, milyen módosítási javaslatokkal tudnának szolgálni annak érdekében, hogy a közösségi szolgálat elérje céljait. Az interjúalanyok hangsúlyozták, hogy fontos lenne olyan fórumokat, képzéseket szervezni, ahol lehetőségük nyílik mind a koordinátoroknak, mind a tanároknak megosztani egymás között a tapasztalataikat, jó gyakorlataikat, és egymást segítve egy olyan támogató rendszert kiépíteni, mely segíti a szolgálat során felmerül problémák megoldását.

„Hát több információ kellene szerintem. Több ilyen, több képzés mondjuk az iksz-koordinátoroknak, például jó gyakorlatokból. Öö, olyan, hogy fejezzem ki magam, olyan alkalmak, ahol megoszthatják egymással mondjuk a pedagógusok is a tapasztalataikat, akár pozitiv, akár negativ. Vagy ahol a kérdéseikre választ kaphatnak, mert írnak egy e-mailt és telefonálnak, de lehet, hogy ez a probléma, ami náluk felmerült, még másik száz iskolában is felmerült. Úgyhogy valami kis rendszert kellene még szerintem belevinni." (Kulturális és közösségi terület)

Az interjúalanyok javasolták azt is, hogy nagyobb figyelmet kellene arra összpontosítani, hogy minél több fogadószervezettel vegyék fel a kapcsolatot az iskolák. Hisz gyakori, hogy az oktatási intézmény néhány szervezettel köt szerződést, ezzel lekorlátozva a diák választási lehetőségét, mely jelentős mértékben befolyásolja a szolgálattal kapcsolatos élményeit és tapasztalatait. Szükségszerü lenne tehát az iskoláknak bővíteni a fogadóintézmény-kínálati listáját, és a lehető legtöbb intézménnyel szerződést kötni. 
Így a kötelezőség mellett megjelenhetne a szabadság érzése is a diákoknál, az a tudat, hogy lehet, hogy kötelező a közösségi szolgálat, de valóban nagyon sok lehetőség közül szabadon dönthetnek, mint például az elvégzésének a helyéröl és az egy fogadószervezetnél eltöltött időröl.

„Legyen minden befogadó intézménnyel az iskoláknak szerzödésük. A gyereknek, vagyis a diáknak minél több, nagyobb legyen a skála, hogy választhasson, hogy hova mehessen, vagy pedig több intézményhez tudjon ellátogatni. Ezen változtatnék. Mert van olyan, ahol három-négy intézménybe [mehet a diák], ezt mindenképpen." (Kulturális és közösségi terület)

Fontos lenne fokozottabb ellenőrzést bevezetni a közösségi szolgálat során, hogy ellenőrizhetőbbé váljon mind a diák, mind a fogadóintézmény. Bár a közösségi szolgálati napló részben ellenőrzi a diák tevékenységét, ez azonban kevés ahhoz, hogy a különböző visszaéléseket visszaszorítsa. Szükséges lenne, akár a személyes látogatások során ellenőrizni, hogy a fiatalok hol, milyen tevékenységet végeznek. Addig, míg egy szigorítottabb rendszer nem jön létre, sem a diákok, sem a fogadószervezetek nem érzik a rendszer komolyságát, és sokaknál nem elsősorban a végzett tevékenységen, hanem annak leigazolásán, leigazoltatásán lesz a fő hangsúly.

„Még ha vannak hibái és több sebböl vérzik a dolog meg, meg, amiket ugye mondtam, hogy ez a rosszul volt lekommunikálva az egész dolog, öö, nem tudom. Szerintem semmit. Semmit. Ha változtatnánk rajta, akkor, akkor csak ezeket az apró dolgokat, egységes kommunikáció, egységes, öö, egységes követelési rendszer, esetleg egy jobb ellenörzés, tehát szigorúbb ellenörzés." (Kulturális és közösségi terület)

Említésre került az is, hogy szükségszerü lenne a szülőket is akár személyesen bevonni a közösségi szolgálatba, hisz tudjuk, hogy a szülöi minta, szülői vélemények nagymértékben befolyásolják a diákok szolgálathoz való viszonyát. Ha a szülők is ellátogatnak a fogadóintézményhez, megismerhetik annak tevékenységi körét, pozitív tapasztalatok hatására motiválhatják a gyermekeiket az aktívabb állampolgári magatartás elsajátítására, és arra, hogy szívesebben vállaljanak részt a szervezetek életében. Akár a szülök maguk is motiváltabbakká válhatnak abban, hogy önkéntesként segítsenek egy szervezet munkájában.

„Nagyobb szabadságot kellene adni a gyereknek, mert vagy egy az, hogy ö érzi, hogy neki mi a jobb, vagy tudja vagy sejti. Ugyanakkor én azt gondolnám, hogy a szülönek ebbe jobban kellene részt venni." (Szociális és jótékonysági terület)

Összességében látható, hogy a közösségi szolgálat kiforratlanságából adódóan számos problémával kell szembenézniük mind a diákoknak, mind a fogadószervezeteknek. Bodó (2015) kutatásai is beszámolnak a kezdetleges nehézségekről a pedagógusok oldaláról. Ahhoz, hogy lényegi változások történjenek, a fogadószervezetek koordinátorai szerint rendszerszintü változtatásokra is szükség van. Számos probléma azonban nem feltétlenül követel meg törvényi változtatást, például az iskolák fogadószervezetekkel kialakított kapcsolatainak bővítése, vagy a szülök bevonása. Fontos lenne a fogadószervezetek figyelmét felhívni arra, hogy ők maguk is tehetnek olyan változtatásokat, amelyek segítik egyrészt saját munkájukat, másrészt a szolgálati tevékenység müködésének zökkenőmentesebb kialakítását. 


\section{Összegzés}

Tanulmányom elsődleges célja az volt, hogy megvizsgáljam a közösségi szolgálat egyik igen jelentős szereplöjének, a fogadószervezetek koordinátorainak tapasztalatait a közösségi szolgálattal kapcsolatban. Fontosnak tartottam vizsgálni azt a kérdést, hogy létrejön-e a tényleges értékteremtés, és a hasznos tevékenységvégzés a szolgálat során, valamint képes-e növelni a civil tudatosságot és aktivitást a diákok körében, vagy mindössze az 50 óra teljesítéséröl szól a program.

Mind a hazai, mind a nemzetközi szakirodalom alátámasztja azt, hogy a gazdasági, társadalmi és politikai berendezkedés egyaránt megkívánja a civil tudatosság, a társadalmi cselekvésekbe való bekapcsolódás és az önkéntességre való hajlandóság növelését. Látható, hogy mindezek egyéni és társadalmi hasznosulása jelentős. Bár az iskolai közösségi szolgálat végleges formájának kialakítása egy folyamat, mely során a szereplők mindegyikének vannak javaslatai arra vonatkozóan, hogy mi szükséges ahhoz, hogy a program minél hamarabb elnyerje ideális formáját.

A kvalitatív vizsgálati eredmények azt mutatták, hogy a koordinátorok a közösségi szolgálatot szükségszerü és fontos dolognak tartják, mely motiválhatja a diákokat az aktívabb állampolgári létre. Az interjúalanyok úgy vélik, hogy a fogadóintézmények nyitottak arra, hogy a diákok a szervezet életébe betekintést nyerjenek. Azonban az, hogy mennyire képes a fiatal eredményesen bekapcsolódni a közös munkába, az a személyiségén, motivációján és együttmüködési készségén múlik. A koordinátorok bíznak abban, hogy a szolgálat hatására nőni fog az önkénteseik száma, hisz kis híján mindegyikük beszámolt hasonló tapasztalatról. Az interjúalanyok szerint a szülök közösségi szolgálatba való bevonása megoldást nyújthatna a pozitívabb attitüdök kialakításában a fiataloknál.

Az interjúalanyok kifogásolták a szolgálat kötelező jellegét, mely szerintük nagymértékben hozzájárulhat a diákok negatív attitüdjeinek kialakulásához, valamint azt is nehezményezték, hogy hiányzik egy ellenőrző hatóság, amely felügyeli a visszaéléseket - elsősorban az órák leigazoltatását - mind a diákok, mind a fogóintézmények részéröl.

Az említett problémák megoldásához azonban nem minden esetben szükségszerü a törvényi változtatás. Az interjúk alapján úgy tűnik, olykor a fogadószervezetek diákokhoz való hozzáállása sem helytálló, gondoljunk csak az önkéntes és közösségi szolgálatos diákok közötti munka kiosztására. Fontos lenne hangsúlyozni körükben azt, hogy ők maguk is részesei a közösségi szolgálatnak, és annak sikere vagy sikertelensége a pedagógusokon és a diákok túl, egyharmad részt az ő felelősségük is.

\section{Irodalom}

A nemzeti köznevelésröl szóló 2011. évi CXC. törvény 4 . $§ 15$.

Bauer Béla, Pillók Péter, Ruff Tamás, Szabó Andrea, Szanyi F. Eleonóra \& Székely Levente (2016). Magyar Ifjúság Kutatás. Az ifjúságkutatás első eredményei. Ezek a mai magyar fiatalok. Budapest: Új Nemzedék Központ. http://www. ujnemzedek.hu/sites/default/files/magyar_ ifjusag_2016_a4_web.pdf Utolsó letöltés: 2018.05 .05 .

Bocsi Veronika, Fényes Hajnalka \& Markos Valéria (2017). Motives of volunteering and values of work among higher education students. Citizenship,
Social and Economic Education. 16(2), 117-131. DOI: $10.1177 / 2047173417717061$

Bodó Márton (2014). A közösségi szolgálat 2011-es bevezetése és tanulságai. Új Pedagógiai Szemle, 64(3-4), 47-68.

Bodó Márton (2016). A pedagógusszerep és az Iskolai Közösségi Szolgálat. Kapocs, 15(69), 3-14.

Bodó Márton \& Schnellbach S. Dóra (2014). Hol tart ma a szociális, társadalmi érzékenyítés az általános iskolákban? In: Buda András \& Kiss Endre (szerk.). Interdiszciplináris pedagógia és a fenntartható fejlödés: a VIII. Kiss Árpád Emlékkonferencia elöadásainak szerkesztett változata. Debrecen: Debreceni Egyetem Neveléstudományok Intézete. 322-333. 
Brown, E. (1999). The Scope of Volunteer Activity and Public Service. Law and Contemporary Problems. 62(4), 17-42. DOI: 10.2307/1192265

Cohen, J. L. \& Arató, A. (1992). Civil Society and Political Theory. Cambridge: The MIT Press.

Czike Klára \& Kuti Éva (2006): Önkéntesség, jótékonyság, társadalmi integráció. Budapest: Nonprofit Kutatócsoport és Önkéntes Központ Alapítvány.

Eurobarométer (2011). Önkéntesség és generációk közötti szolidaritás. http://www.europarl.europa.eu/ pdf/eurobarometre/2011/juillet/04_07/rapport_\%20 eb75_2_\%20benevolat_hu.pdf. Utolsó letöltés: 2015.01.06.

F. Tóth András \& Nagy Ádám (2009). Humán infrastruktúra: Önkéntesség - foglalkoztatás - tagság. Civil Szemle, 8(1-2), 59-77.

Galambos Rita \& Matolcsi Zsuzsa (2012). Módszertani kézikönyv iskolai közösségi szolgálati tevékenységek és projektek megvalósitásához. Budapest: Demokratikus Ifjúságért Alapítvány.

Gellner, E. (2004). A szabadság feltételei. A civil társadalom és vetélytársai. Budapest: Typotex.

Glózer Rita (2000). Civil szervezetek - kommunikációelméleti keretben. In. Civil-évkönyv 1999. Budapest: Európa Ház. 18-24.

Jancsák Csaba (2007). Ifjúsági civil szervezetek a dél-alföldi régióban. Civil Szemle, 4(3-4), 69-87.

Központi Statisztikai Hivatal (2016). Az önkéntes munka jellemzöi. https://www.ksh.hu/docs/hun/ xftp/idoszaki/pdf/onkentes.pdf. Utolsó letöltés: 2017.11.05.

Központi Statisztikai Hivatal (2016). KSH: Idősoros éves adatok - Gazdasági és nonprofit szervezetek, vállalkozások teljesitménye. https://www.ksh.hu/ stadat_eves_3_2 Utolsó letöltés: 2017.01.10.

Kuti Éva (1996). A nonprofit szervezetek szerepe a kilencvenes évek magyar társadalmában és gazdaságában. Közgazdasági szemle, 43(1), 18-33.

Kuti Éva (1998). Hivjuk talán nonprofitnak... Budapest: Nonprofit Kutatócsoport.

Markos Valéria (2015). Az iskolai közösségi szolgálat iránti attitüdök a középiskolások körében. In. Juvenilia VI. Debreceni bölcsész diákkörösök antológiája. Debrecen: Printart-Press Kf. 209-224.

Markos Valéria (2016a). A nyíregyházi középiskolás diákok iskolai közösségi szolgálattal kapcsolatos tapasztalatainak vizsgálata. Párbeszéd Folyóirat, 3(4), http://parbeszed.lib.unideb.hu/megjelent/ html/585a817dc9d71. Utolsó letöltés: 2017.01.02.

Markos Valéria (2016b). Közösségi szolgálat vagy önkéntesség. Educatio, 25(3), 444-450.

Matolcsi Zsuzsa (2013). Iskolai közösségi szolgálat, mint pedagógiai eszköz. Neveléstudomány, 1(4), 70-83.
Nárai Márta (2004). A civil szervezetek szerepe és jelentősége az egyének, közösségek, illetve a társadalom számára. Educatio, 13(4), 616-634.

Nemzeti Köznevelésről szóló 2011. évi CXC. törvény, $4 . \S$ (15.), $6 \S$ (4.)

Nemzeti Önkéntes Stratégia 2012-2020. http://20102014 . kormany.hu/down load/4/98/ d $0000 / \%$ C $3 \% 96$ n k \% C $3 \%$ A 9 n t e s \% 20 strat\%C3\%A9gia.pdf. Utolsó leltöltés: 2017.11.08.

Putnam R. D. (1995). Tuning In, Tuning Out: The Strange Dissapearance of Social Capital in America. Political Science and Politics. 28(4), 664-683. DOI: 10.2307/420517

Putnam R. D. (2000). Bowling alone. The collapse and revival of American community. New York: Simon and Schuster.

Rozgonyi Zoltán (2014). Iskolai közösségi szolgálat. http://rpi.reformatus.hu/hatteranyagok/RPI\%20 Orsz\%C3\%A1gj\%C3\%A1r\%C3\%B3\%202014.\%20 08.28-29.\%20RZ.pdf. Utolsó letöltés: 2017.11.01.

Smith, S. R. (1999). Comment: Volunteering and Community service. Law and Contemporary Problems. 62(4), 169-177. DOI: 10.2307/1192271

Székely Levente (2012). Magyar Ifjúság. Budapest: Új Nemzedék.

Szigeti Ferenc Albert (2003). Az önkéntesség szerepe a fejlett piacgazdaságban. http://www.3sz.hu/ sites/default/files/uploaded/az_onkentesseg_ szerepe_a_fejlett_piacgazdasagban_szigeti_ ferenc_albert_szakdolgozat_2003.pdf. Utolsó letöltés: $20 \overline{17} .11 .1 \overline{8}$.

Vajda Ágnes (1997). A nonprofit szervezetek szerep a társadalomépítésben. INFO-Társadalomtudomány, 42, 23-30.

Wilson, J. \& Musick, M. (1998). The Effects of Volunteering on the Volunteer. Law and Contemporary Problems. 62(4), 141-168.

Wollebaek, D. \& Selle, P. (2002). Does Participation in Voluntary Associations Contribute to Social Capital? The Impact of Intensity, Scope, and Type. Nonprofit and Voluntary Sector Quarterly. 31(1), 32-61. DOI: 10.1177/0899764002311002

Zentai László (2006). Önkéntes segítés Magyarországon ma és holnap. Polgári Szemle, 2(5), https:// polgariszemle.hu/archivum/22-2006-majus-2evfolyam-5 - szam/10 0 - oenkentes - segites magyarorszagon-ma-es-holnap. Utolsó letöltés: 2017.11.18. 